\title{
Final Report to the Department of Energy for Grant DE-FG02-01ER54663
}

Funds provided from this DOE award were used to support student participation in the $54^{\text {th }}$ Gaseous Electronics Conference held at Penn State University October 9-12, 2001.

Specifically, DOE funds were distributed to 27 different graduate students, providing $\$ 400-\$ 600$ per student to help defray costs associated with conference participation. Each of the students receiving such support presented research results at the conference.

Supplementing the DOE resources provided were donations from several industrial firms. Additional funds from industry allowed for a $\$ 140.00$ student registration fee, which was $\$ 100.00$ below the normal early registration fee of $\$ 250.00$. Finally, the above resources supported two Student Awards for Excellence awarded for the two best technical presentations at the conference by students.

Submitted by:

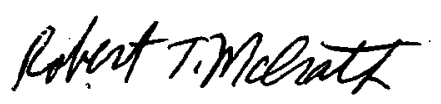

Robert T. McGrath

Professor of Engineering Science \& Mechanics

DOE Patent Clearance Granted

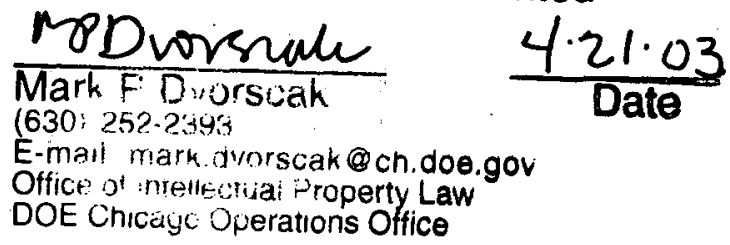




\section{DISCLAIMER}

This report was prepared as an account of work sponsored by an agency of the United States Government. Neither the United States Government nor any agency thereof, nor any of their employees, makes any warranty, express or implied, or assumes any legal liability or responsibility for the accuracy, completeness, or usefulness of any information, apparatus, product, or process disclosed, or represents that its use would not infringe privately owned rights. Reference herein to any specific commercial product, process, or service by trade name, trademark, manufacturer, or otherwise does not necessarily constitute or imply its endorsement, recommendation, or favoring by the United States Government or any agency thereof. The views and opinions of authors expressed herein do not necessarily state or reflect those of the United States Government or any agency thereof. 


\section{DISCLAIMER}

\section{Portions of this document may be illegible in electronic image products. Images are produced from the best available original document.}

